\title{
Universities, Politics and Development in Northern Ontario and Northern Sweden: A Comparative Analysis
}

\author{
GEOFFREY R. WELLER* and ROBERT G. ROSEHART**
}

\begin{abstract}
Both Ontario and Sweden established universities in their northern regions in the nineteen sixties. This article begins by noting that the two regions are similar in very many ways and that the pressures exerted in both for the establishment of postsecondary educational institutions were much the same. The article continues by comparing the rationales and principles upon which the two sets of universities were founded. It is indicated that while the principle of regional access dominated in northern Ontario the principle of regional service dominated in northern Sweden. Thus the northern Ontario universities began as small, basically undergraduate Arts and Science institutions while the universities in northern Sweden began as specialized professional institutes intended to solve specific regional problems and disparities. The article goes on to analyse the academic, financial and geographic problems faced by the two sets of northern universities since they were founded and the developments that have taken place. An assessment is then made of the successes and failures of the two systems and it is argued that although some convergence has taken place the Swedish approach has been the more successful of the two.
\end{abstract}

\section{RÉSUMÉ}

L'Ontario et la Suède ont, parallèlement, créé des universités dans leurs régions du nord au cours des années soixante. Le présent article commence en mentionnant la similitude des deux régions, sous bien des aspects, tout comme celle des pressions exercées dans les deux cas, au sujet de la création d'instituts universitaires. Cet article se poursuit avec une comparaison entre les raisonnements et les principes sur lesquels les deux établissements universitaires furent fondés. Il est précisé que dans le nord de l' Ontario le principe prédominant était la difficulté d'accès au point de vue régional, alors que dans le nord de la Suède

* Vice-President (Academic), Lakehead University, Thunder Bay, Ontario.

** President, Lakehead University, Thunder Bay, Ontario 
c'était le principe du service régional qui prédominait. C'est pourquoi les universités du nord de l'Ontario furent au début de petites institutions, préparant principalement à la licence d'arts et de sciences, alors que les universités du nord de la Suède furent dès le départ des établissements professionnels spécialisés, dont le but était de résoudre les problèmes et les disparités régionales spécifiques. L'article aborde ensuite l'analyse des problèmes académiques, financiers et géographiques que rencontrent les deux établissements universitaires depuis leur création, ainsi que les aménagements qui y ont été entrepris. Il fait ensuite état d'une évaluation des succès et des échecs concernant les deux systèmes et affirme que, malgré une certaine convergence, l'approche suédoise a été la plus fructueuse des deux.

\section{INTRODUCTION}

Ontario and Sweden are similar in many ways. Their populations are roughly the same as are the nature of their economies, geography and climate. Moreover, the northern regions of Sweden and Ontario are also similar. Both are large geographic areas in relation to the southern parts of their respective political jurisdictions. They have similar economies based upon natural resources. The major industries are forestry, mining, tourism and power generation. The standard of living as well as the social and cultural conditions of life are similar and, more importantly, significantly lower in each case than for the southern regions of the two political units. This has produced a similar political culture in which radical politics is particularly notable and in which there has been a relatively high degree of political unrest.

Both Sweden and Ontario established institutions of higher education in their northern regions at roughly the same time. Laurentian University was established in 1960 and Lakehead university in 1965. Laurentian has several small constituent colleges located at North Bay (Nippissing College), Hearst (Hearst College) and Sault Ste. Marie (Algoma College). A full university in Umea was established in 1963, a College or technical university in Lulea in 1977 and Schools of Higher Education in Ostersund, Sundsvall/Harnosand and Gavle/Sandviken in the same year. In most cases, the institutions established were in both northern Ontario and northern Sweden expansions of smaller more restricted pre-existing higher educational institutions.

The purpose of this paper is to see if there are any lessons that can be learned from a comparison of the two northern university systems. Essentially, use is being made of what in the literature on comparative politics is normally termed a 'most similar systems' approach. The paper begins by comparing the nature of the two regions. This is followed by an analysis of the motivations for developing northern universities in the two regions. Then the many problems facing the two systems are compared. An analysis is then made of the various policy outcomes that have resulted from the establishment of the northern university system. Finally, an estimation is made of what the future is likely to hold for each system. 


\section{THE REGIONS COMPARED}

Both northern Sweden and northern Ontario cover large land areas and comprise a large percentage of the total for their respective jurisdictions. Northern Sweden, or Norrland, is made up of the five northern countries of Sweden - Norbotten, Vasterbotten, Jamtland, Vasternorrland and Gavleborg. These cover roughly $60 \%$ of the total land area of Sweden or 102,500 square miles. Northern Ontario consists of the area within the jurisdiction of the Ontario Ministry of Northern Affairs. It covers roughly $90 \%$ of Ontario's land mass or 370,000 square miles. The major cities and towns of both regions are widely scattered and located a long way from their respective capitals. Lulea is 618 miles from Stockholm and Thunder Bay is 1,000 miles from Toronto. These distances were magnified until recently in Ontario because ground transportation was not always easy and there was, in fact, no paved highway around the north of Lake Superior until 1965. (Lane, 1983, pp 25-29, Weller, 1983, pp 1-6)

Both northern Sweden and northern Ontario are located in areas that were heavily glaciated. The geology of both areas is rich in mineral resources but is such that it makes agriculture difficult on any significant scale, a fact only learned in northern Ontario after many unsuccessful attempts to settle the little agricultural land that was available. The climate of both regions is harsh which also mitigates against agricultural settlement. Both areas have cool summers and cold to very cold winters and a wide temperature range. Most of the land area of both regions is covered by forests but in northern Ontario, the northern third is above the tree line and consists of swampy lowlands bordering on Hudson's Bay.

While both northern Sweden and northern Ontario have large land areas their populations constitute small percentages of the total for their jurisdictions. Norrland has $18 \%$ of the total Swedish population or approximately 1.2 million out of 8.3 million. Northern Ontario has less than $10 \%$ with a population of 805,000 out of a provincial total of 8.2 million. In both cases the proportion of the total population is declining. The population of both areas is widely scattered and there are relatively few large population centres. None of the major centres in Norrland exceeds 100,000 with all of the major centres except Ostersund being spread along the Baltic Coast. Going from north to south the major centres are Lulea $(67,000)$, Skelleftea $(73,000)$, Umea $(80,000)$, Harnosand $(27,000)$, Sundsvall $(94,000)$, Ostersund $(55,000)$ and Gavle $(87,000)$. Two of the major centres in northern Ontario exceed 100,000 . They are Sudbury, the regional centre for Northeastern Ontario, with a population of over 150,000 and Thunder Bay, the regional centre for Northwestern Ontario, with a population of 112,000 . Northeastern Ontario is the largest sub-region with a total population of 580,000 and a few cities of reasonable size including Timmins $(45,000)$, Sault Ste. Marie $(80,000)$ and North Bay $(50,000)$. In Northwestern Ontario, Thunder Bay is the only city of any size at all with approximately half of the regions total population of 225,000 . The other towns are widely scattered and very small with Kenora being the largest at 12,000. Some of the more northerly communities, especially the native communities, are very small and extremely remote. The populations of many of the cities and towns 


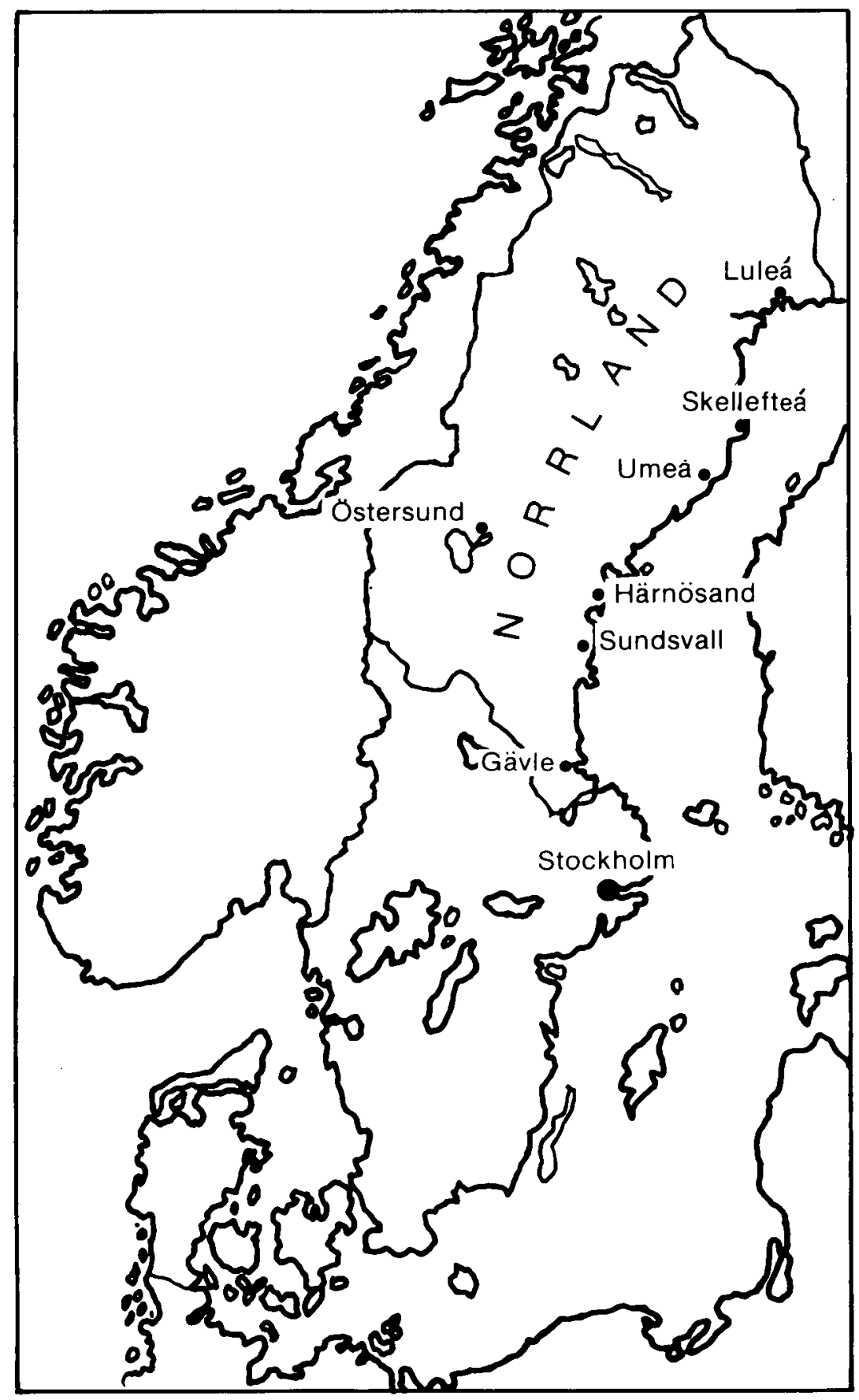




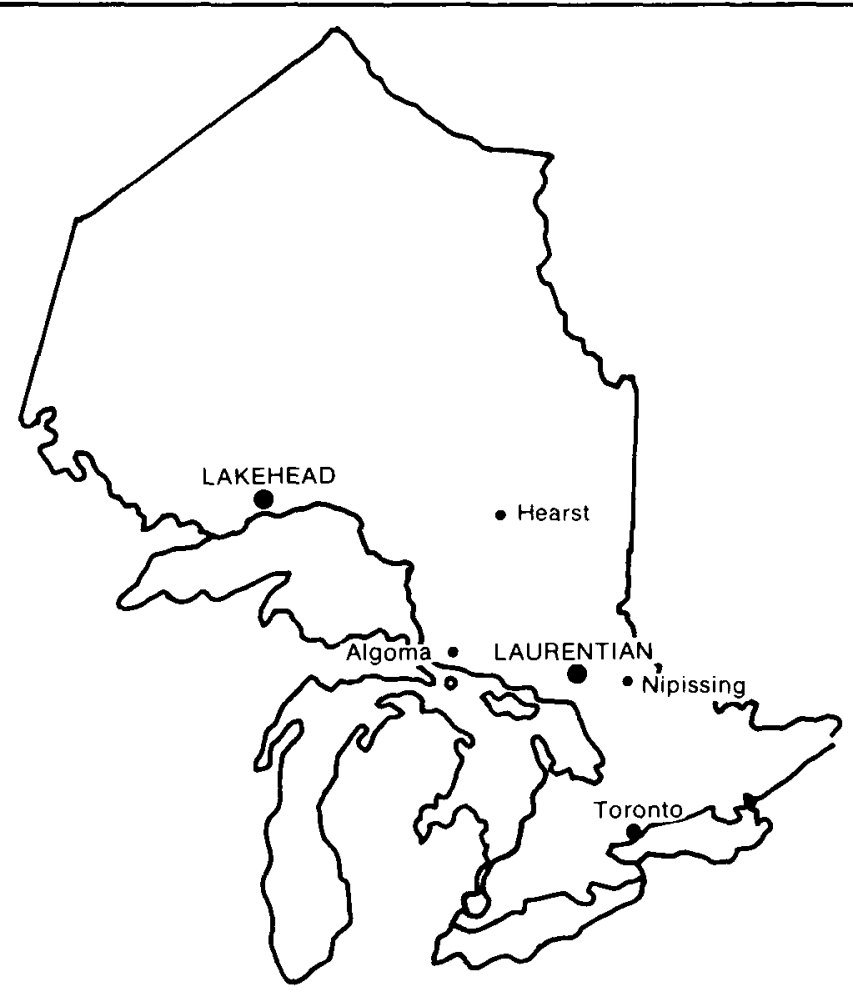

have gone up and down with the boom and bust cycle of the primary industries upon which most are dependent.

The population of northern Ontario is more mixed racially, ethnically and in terms of religious conviction than is that of Norrland. While there are some 20,000 Lapps in Norrland they constitute a lesser percentage than the Indian population of northern Ontario. The Indian population constitutes approximately $10 \%$ of the total and consists of roughly one half status Indians and one half non-status Indians and metis. The Indian population is quite rapidly expanding and is an increasing percentage of the regional total. The non-Indian population in northern Ontario is ethnically very mixed. The largest grouping is of British ancestry, with a very strong Scottish influence, but there is a very significant (30\%) French Canadian population in Northeastern Ontario. There are significant percentages of people with Ukranian, Scandinavian, Polish, German and Italian ancestry.

The economies of Norrland and northern Ontario are both resource based. The four big employers are the forest industries, mining, tourism and power generation. Mining and forestry are found all over Norrland while mining in northern Ontario is concentrated in the northeast and forestry in the northwest. Hydroelectric power generation is important in both Norrland and northern 
Ontario but the resources of Norrland $(83 \%$ of the total hydroelectric power capacity of Sweden) is fully utilized whereas a little capacity remains in northern Ontario, although it would not be cheap to exploit. In both cases the natural resources of the region have been a big and vital component of the creation of wealth in Sweden and Ontario. Because of the need to export bulk commodities from Norrland and northern Ontario the transportation industry is also of importance. There are very few secondary manufacturing industries in Norrland or northern Ontario and, as has been observed, the agricultural sector is not a major part of either economy.

In both Norrland and northern Ontario, a traditional economy of hunting, fishing and trapping exists along with the resource exploitation economy but it involves a much more significant proportion of the population of northern Ontario than Norrland. The northern Ontario of the traditional economy is the remote native north of tiny scattered communities which is relatively far less affluent.

The geography of the regions and the nature of their economies have combined to create a lack of cohesiveness. Neither Norrland nor northern Ontario has an integrated, reasonably self-reliant, regional economy. The economies have been structured largely on the basis of the needs of southern regions. This is clearly reflected in the transportation networks which have historically been and are still largely structured to facilitate the movement of bulk commodities out of the region and, especially in northern Ontario, not for the purpose of intraregional communication. The lack of integration in the regional economy is partly due to the fact that most of the major industries are owned and controlled by groups headquartered outside the regions with, thereby, relatively little interest in developing integrated regional economies.

The nature of the economies of the regions, their population characteristics and lack of regional cohesiveness all clearly indicate that they are both hinterlands of their respective southern regions. This is also indicated by the relatively lower level of economic well-being and lower level of servicing in nearly all areas including, as we shall see, university facilities. The differences between Norrland and southern Sweden are great and the residents of Norrland have traditionally been poor compared with those of southern Sweden even though recent decades have seen some improvement. The differences are also clearly noticeable in northern Ontario in terms not only of income but also of health, education and other services.

There is, therefore, an atmosphere in both Norrland and northern Ontario in which the local population feels exploited, underpriviledged, alienated and unable to control either their own destiny or that of their respective regions. This has led to radical politics in both areas. The socialist vote has been stronger in Norrland than in southern Sweden and Norrbotten, Vasternorrland and Gavleborg have been strongholds of Swedish Communism. (Lane, 1983, p. 28) In northern Ontario, the social democratic New Democratic Party (NDP) has traditionally been strong and is the second party in the region. In addition, there have been occasional calls for the creation of a separate province of northern Ontario. While these calls have been 
distinctly 'fringe' they are of some significance. (Scott, 1975, Miller, 1980, Weller, 1977, Weller, 1980) Both Norrland and northern Ontario also have records of radical labour action. As Lane puts it "Norrland is well known for the only episode of industrial violence in the birth of the Swedish welfare society - the killing of four workers in Adalen in Vasternorrland". (Lane, 1983, p. 28)

\section{THE RATIONALES FOR THE INTRODUCTION OF UNIVERSITY EDUCATION}

There was no single coherent plan for the introduction of higher education in either northern Sweden or northern Ontario. In both cases the systems grew up piecemeal and largely as the result of local pressures. The rationales for the initial creation of the two systems were, however, markedly different. In Norrland the arguments that were persuasive were nearly always practical in the sense of arguing the need for institutions of higher education to meet practical needs. In northern Ontario the arguments that were persuasive were nearly always related to the need for access to the general university system. In addition, the development of the university system in Norrland has been more closely linked with regional development plans. Thus, although the piecemeal nature and timing of the introduction of universities was similar in the two countries the nature of the institutions established was quite different.

The major or persuasive rationales for the development of universities in Norrland were largely practical and based upon need. The event that sparked the agitation for a university to be located in northern Sweden appears to have been the 1929-31 investigations of health conditions in Norrland. (Lane, 1983, p. 125) As Rune Premfors states it "the study illustrated the staggering disparities that existed between that region and other parts of Sweden. An important reason for such difference was obviously the lack of medical doctors and dentists". (Premfors, 1984 , p. 88) Regional and local interests thereafter pressured for local training institutions to be built. Initially, however, attempts were made to recruit doctors and dentists in the south for work in the north but this did not have particularly effective results.

In 1951, the government set up a commission to investigate the need for the expansion of the training of odontologists and, in 1953, the Commission recommended the establishment of dental training facilities at Umea. In 1957, the first students to be taught at the school (and at a school of Higher Education in Norrland) began their training. In 1956, a commission into the training of doctors submitted a report which rejected the idea of a medical school being established in Norrland and argued that the existing medical schools should be expanded. Within a year, however, pressure from two members of the Riksdag from Umea and the Chancellor of the Universities as well as the Head of the Medical Board had succeeded in persuading the government to establish a medical school in Umea. The full training of both dentists and doctors did not, however, become established until 1965. Similar arguments related to need were made in relation to teaching and 
a school for the training of domestic science teachers was established in 1948, nursery school teachers in 1965 and general teachers in 1967. The same practical arguments were made concerning social work and a school for social work was created in 1962. (Lane, 1984)

However, considerations of access were not entirely absent from the decision to establish a University in Umea although even so access was thought of as being to subjects of practical use. In 1955, the government appointed a University Commission to investigate the likely expansion of demand, to plan expansion of the system, and to see if a university should be created in Norrland. The Commission recommended, in 1959, that the existing universities be expanded and no new university be created in Umea. The government, however, decided a university should be established and set up, in 1962, the Umea committee to plan a small university to concentrate on instruction largely in the sciences and social sciences with practical subjects such as the training of public administrators and economists being stressed. In 1963, the University of Umea began to operate. In 1964, the medical and dental schools were amalgamated to the university. In 1968, a Faculty of Arts was added. Finally, in 1977, the schools for the training of domestic science teachers, nursery school teachers, teachers and social workers were amalgamated with the University of Umea. (Lane, 1983, 47-64; Premfors, 1984)

The Swedish University systems expansion beyond Umea to Lulea also resulted from the paramountcy of the argument of practical need. There had been an expansion of technological higher education, in 1960, in response to increased demand with the expansion of the two existing schools of technology in Stockholm and Gothenburg (Chalmers Institute) and the addition of a third one at Lund. Demand continued to increase and consideration was thus given to the creation of further institutes. One was established in Linkoping in 1965. In 1966, the government appointed a commission (the so-called Norrland Commission) to come up with a proposal for an institute in Norrland. In 1969, the Commission reported and argued the need for an institute to stimulate economic development in the north. In 1971, the Lulea Institute of Technology was created. In 1977, all of the other training schools that had been established piecemeal (nursery school teachers in 1963, teachers training in 1968, music in 1977 and vocational training in 1976) were amalgamated with the Lulea Institute of Technology to form the College of Lulea. (Lane, 1983; Premfors, 1984)

The major or persuasive rationale for the development of universities in northern Ontario was that of access not of practical need related to regional development as in Norrland. There was very little questioning of the nature of the education or the type of institutions to which expanded access was now to be made possible. The northern universities, when established, were really seen as necessary only for more convenient access to the university system by those living in the northern regions of the province. It is not surprising, therefore, that they tended to be largely reflections of southern institutions in both their programming and structure. There was very little effort to make them northern in either respect and 
there was certainly no conception that they might be used as one of the engines of regional development or to combat a regional undersupply of doctors, dentists, teachers, social workers or any other type of professionals. Perhaps this was because there had been no equivalent of the 1929 study of health conditions in Norrland that seemed to spark concern in that region. (Weller, 1983; Axelrod, 1982; McLarty, 1979)

A small Technical Institute was founded in Thunder Bay in 1945. When local pressure for its upgrading coincided with the large increase in potential enrolment in the 1960's it was duly transformed into a University in 1965. It thus became the regional access point for Northwestern Ontario. As has been indicated previously, there were no other towns of any size so there was really only one possible site.

A far more complicated situation existed in Northeastern Ontario because there were many more cities of a reasonable size and there were a number of institutions that wished to achieve full university status. One of these was the so-called University of Sudbury, a small catholic college, with (from 1959 on) an affiliated college in the tiny town of Hearst. Groups of businessmen in several centres were pushing hard for the establishment of universities in their communities and the Anglican and United Churches both wanted to establish universities in Sudbury. It was clear that Northeastern Ontario could not support six or seven independent universities so the government approved a compromise which did not solve the problem but did enable them to respond to popular pressure. A Laurentian University Act was passed in 1960 which allowed for the federation of church and non-church related bodies. This eventually led to a complicated structure which meant Laurentian University, as it became called, consisted of four colleges in Sudbury and three colleges in other communities. The colleges in Sudbury were University College (non-denominational), University of Sudbury (Catholic), Huntington College (United Church) and Thorneloe College (Anglican). The affiliated colleges were the College de Hearst (Hearst), Algoma College (Sault Ste. Marie) and Nipissing College (North Bay). An added complication was that the new university was to reflect the linguistic split in the region between French and English by being a bilingual institution. While the denominational colleges in Sudbury now have only a small role in teaching and the Sudbury campus is essentially a united non-denominational institution, there is still some rivalry between the affiliated colleges and the main campus.

Sweden established an ad hoc commission in 1968 , known as U68, which was to investigate the future regionalization of higher education in the country. 'Higher Education' was broadened to mean all postsecondary education. U68 proposed 14 towns or pairs of towns be designated as 'growth centres'. But a working party composed of Parliamentarians, appointed in 1974, proposed a much more elaborate framework for regional planning. It proposed six regions with a full university as its core and having a regional board to govern it. These six regions were accepted and established in 1975.

The university system was thus linked with the general goals of Swedish regional development policy. This policy was directed at achieving greater social 
equality by region, regional economic development, and a balance by region of public and private services. An attempt was made to limit the growth of the major metropolitan areas and create a number of alternative growth centres. In the early 1980's, a decision was even taken to relocate a number of government agencies. The 1968 Commission stated that "regionalization of the provision of higher education would effectively contribute to equality of participation, regional economic development, a better study environment for students, and closer ties between those involved in higher education and the local community." (Premfors 1984, p. 95) Background studies indicated that higher education had the most positive effect on economic development of various different activities and a study of the effect of the founding of the University of Umea showed it had a wide ranging effect on the local economy, especially in terms of employment.

The plans for regionalization of the system of higher education had the support of the Social Democratic Party, the Center Party and the Communist Party. The Center Party was especially favourably disposed. Since these parties constituted a majority in the Rikstag it was clear the proposals for regionalization would be successful despite the opposition of the Conservative Party and many Liberals. The regionalization policy also had the support of two powerful national trade unions, the TCO (white collar) and the LO (blue collar). The Conservative Party and the Liberals argued that regionalization would add another layer of bureaucracy to the structure of higher education in Sweden. The established universities, rather naturally, opposed regionalization arguing it would thinly spread scarce resources and the new institutions would be second-rate since they would not have a real research base. (O.E.C.D. 1981, Premfors \& Ostergren, 1978, Ministry of Education and Cultural Affairs, 1978)

In northern Ontario, the expansion of the university system in the 1960's was not, as in Sweden, connected with any clear regional development policy. There was a brief flirtation with 'regional' planning in Ontario but it was very vague and had little application to the north. (Department of Treasury and Economics, 1970, Department of Treasury, Economics and Intergovernmental Affairs, 1976, Ontario Economic Council, 1976) Very quickly, the government wished to avoid any reference to the terms. This was largely because it smacked too much of state intervention or 'socialistic' direction of the economy and society. There was not only a general desire not to interfere with 'natural' economic development forces, but also a desire to leave untouched major areas of social policy so that the dominant forces within each policy sector would be blamed rather than the government. This combination of capitalist ideology and a brokerage style of rule meant societal forces, especially organized interest groups, could penetrate the bureaucratic and political systems. (Wilson and Hoffman, 1972; Silcox, 1968; LeDuc and White, 1972)

As far as the Universities were concerned, this style of rule meant that universities were not seen as tools of social policy, certainly not regional development policy, except in the most general terms. Moreover, it meant a hands-off approach that was given the respectable rationalization of "autonomy" 
for the universities and 'non-interference' by government. The result was that when the great pressure for the expansion of universities was felt in the 1960's, that expansion came largely at the established universities and what new universities were established were largely the result of political accommodation rather than any logical plan either for the university system, or the economy, or the regions of the province,

Because of this all of the new institutions, including those in the north of Ontario, were seriously disadvantaged from their very births. In the first place, they were adversely affected by the fact that the goal for the system was simply "access" with little discussion of the nature of the education or the type of institutions to which expanded access was now to be made possible. As a consequence, the older established universities initially kept nearly all of the professional faculties and research capacity and the newer universities, including the two northern universities, simply began as undergraduate arts and science institutions - a complete contrast to the beginnings of the universities in northern Sweden. In the second place, the two northern universities were adversely affected by being placed almost unprotected in what has been termed an "entrepreneurial university system" i.e. a competitive one. (Axelrod, 1982) This system resulted from the deliberate policy of the government not to establish a master plan for the universities, which might have included a clear and specific role for its northern components, but to leave them autonomous and to fund them accordingly. The trick of matching very large state funding with individual autonomy was achieved by a formula financing system tied to the number and level of students each university enrolled annually. This, of course, meant university incomes were determined by the number and type of students they could attract and this, inevitably led to competition among the universities for students. In this competition, the two northern universities were seriously disadvantaged because they had little that was distinctive about them and they had far higher costs because of factors such as distance and climate.

It might be argued there could have been some kind of 'hidden agenda' in Ontario concerning the northern universities. Firstly, much of the politics in northern Ontario has been described as one of 'keeping the natives happy' but in fact doing very little to change the basic hinterland-metropolis relationship while making certain gestures or giving handouts to mitigate the worst effects of hinterland status. (Weller, 1977) The location of small, basically undergraduate universities in the north could be construed as part of this policy. Secondly, the establishment of Lakehead and Laurentian, with its affiliated colleges, may have been undertaken to prevent or mute intermittent political protest caused by the relatively unstable economies of most northern cities. In other words, they may simply have been reasonably useful ways of injecting public funds into the north to create a degree of economic stability in the larger centres. Universities certainly do have this effect. (Lakehead University, 1983) Finally, if one were quite cynical, yet a third reason could be seen for establishing small basically undergraduate universities without a northern focus in the north. This is that they help educate a 
youthful labour force for jobs that do not exist in the region thus creating the possibility of out-migration. If this mobility did not occur then either the unemployment rate in the north would be considerably higher than it is (with corresponding greater political protest) or the government would have to take more and wider ranging job creation measures than it has in the past. In short, the role originally envisaged for the universities in northern Ontario might have been to actually prevent calls for larger scale development rather than to act as agents of development. (Weller, 1977, p. 744)

\section{THE PROBLEMS OF THE NORTHERN UNIVERSITIES}

The universities in northern Sweden and northern Ontario faced a wide range of problems in the first two decades of their existence. The geographical spread of postsecondary educational resources or the location of such resources was a continuing problem. There were also numerous difficulties that could be lumped together under the title "administrative". There were also a whole series of financial uncertainties. Moreover, each set of institutions has had problems in relating to the regions of which they are a part. Each of these sets or areas of difficulties will be dealt with in turn.

A major problem in both Sweden and Ontario has been the siting and the development of institutions in the various cities and towns in the north. In both cases, this produced some fierce political battles and some long-lasting problems. Jan-Erik Lane has detailed the inter-city rivalry in northern Sweden concerning the original location of the various institutions of higher education in that region. (Lane, 1983) He indicates that it was a very complicated political game in which Umea at first seemed to have all the successes but then suffered reversals. Umea was really first off the mark in pressuring Stockholm for a university and did far more by way of raising local funds and gaining political access for its claim than any other community in the north. With the changed attitude to higher education embodied in the 1977 general reforms and the linkage of higher education to broader plans for regional development, the claims of the other cities in Norrland were listened to and a technical university established in Lulea and smaller colleges at Ostersund and Sundsvall/Harnosand.

With the development of the Regional Board structure in Sweden, a device was put in place that had as one of its prime roles the distribution of higher education resources on a region-wide basis. The Northern Regional Board had broad representation from various social groups and from across the region. While this does not mean, of course, the elimination of problems, there is at least a mechanism in place for dealing with the issues and the central government does not have to become deeply involved in the process as has been the case in northern (especially Northeastern) Ontario.

The distribution of higher education resources around northern Ontario has only been a problem in Northeastern Ontario. Thunder Bay is the only town of any real size in Northwestern Ontario so it was the only logical location. However, in Northeastern Ontario the distribution/location problem has been deep and long- 
lasting and despite a great deal of analysis by various committees of inquiry the government appears hesitant to take any decisive action, presumably for fear of alienating some of the areas or, more particularly, the voters in some of the regions of Northeastern Ontario.

The Laurentian University federation created inter-campus rivalry at its very inception and even now "the institutions often see themselves as being in competition for students". (Ontario Council on University Affairs, 1983, p. 110) Moreover, it has been argued that "there is an unsatisfactory distribution of resources among the institutions and the off-campus programs offered by the institutions are not effectively coordinated." (Ontario Council on University Affairs, 1983, p. 110) The individual constituent campuses have each had their difficulties. The College de Hearst, for example, is located in a small community $(5,000)$ and has had so few students (23 full-time and 500 part-time in 1982) that it has had continual and chronic financial problems. In 1982, the Ministry of Colleges and Universities commissioned an assessment of the long term viability of the College which recommended renewal of the institution be attempted. (Drouin, Paquin and Associates Ltd., 1982) Algoma College, to take another example, has suffered from severe competition from Lake Superior College in Michigan, chronic financial difficulties and lots of internal disputes. Algoma's problems were so great that a Royal Commission of Inquiry, the Whiteside Commission, recommended that the College be closed. (Royal Commission of Inquiry into Algoma University College, 1977)

In The Ontario University System: A Statement of Issues, which was published in 1978, the Ontario Council on University Affairs suggested that "Laurentian and its affiliated university colleges might be integrated into a University of Northeastern Ontario". (Ontario Council on University Affairs, 1979, p. 34) The OCUA later established a committee of the four executive heads of the institutions chaired by an outsider, Dr. A.N. Bourns, to explore the options for structural change in Northeastern Ontario. In October 1981, the committee reported and recommended that a single University of Northeastern Ontario be established. (Ontario Council on University Affairs, 1981) After discussions with the various institutions in the region during which Laurentian and Algoma indicated their support and Nipissing and Hearst their opposition, the OCUA recommended to the government that such a new university be created. In October 1982, the government announced that it accepted the principle of restructuring the university system in Northeastern Ontario. (Stephenson, 1982) At the same time, the government announced that it was establishing a committee (the Parrott Committee) to recommend a structure and a name for the new university. On June 29th, 1983, the Parrott Committee reported, indicating it recommended the name Champlain University and the merging of the four existing institutions into one with a single Board of Governors and Senate and one President. (Committee on University Education in Northeastern Ontario, 1983) The Minister of Colleges and Universities, Dr. Bette Stephenson, while awaiting a study on start up costs for the new university, chose to refer the whole contentious matter to a new inquiry into the entire provincial 
university system (the Bovey Commission) that was established in 1984. To a large degree, the Bovey Commission dodged the issue and simply recommended that two advisory boards, one for the Northeast and one for the Northwest be established. (Commission on the Future Development of the Universities of Ontario, 1984, p. 43) New efforts are now being made by the heads of all the constituent units to redefine the whole relationship.

In terms of administration the two northern universities would at first sight appear to be under completely different regimes. In Sweden there is little autonomy, university employees are civil servants with national pay scales, and there is a great deal of control by the bureaucratic and the political realms. In Ontario the universities are autonomous and there is relatively little by way of a controlling bureaucracy or political strata, at least at the undergraduate level. However, upon closer examination the influence of the central state is not as overburdening in Sweden as one might expect from the formal structures in existence while the 'autonomy' the universities ostensibly have in northern Ontario is somewhat restricted by the manner in which funding is manipulated by the bureaucracy and government.

As a result of the Swedish higher educational reforms of 1977, all the various forms of higher education were combined into an essentially uniform entity. The entire higher educational organisation has the same general rules for admission and all fundamental decisions are made at the central level with all forms of higher education being planned on uniform principles. Intake capacity is, for instance, centrally by subject area as is the distribution of that capacity by institution. It is the National Board of Universities and Colleges in Stockholm which has the responsibility for planning and coordination of higher education and research on a national scale. This pattern of administration is common in Sweden, namely that the responsible Ministry (in this case the Ministry of Education and Cultural Affairs) is relatively small while there are quite large semi-independent national agencies such as the National Board. Perhaps the key units of the Board are the five subject area Planning Committees (each with 18 members). (National Board of Universities and Colleges, 1984)

To a very large degree, the northern institutions of higher education in Sweden do not suffer from anything like the same financial problems as those in northern Ontario. In Sweden, educational and research funding is considered separately but both are essentially related to program or departmental criteria. Moreover, there are six Regional Boards, one of which covers the north, which have fairly substantial additional funds to pay for the delivery of things which meet regional needs. (Lund/Malmo Regional Board of Higher Education, 1984) In northern Ontario, educational and research funding is essentially linked and related to a formula that is enrolment driven. In addition, off campus programming is also related to the formula and although it is given extra weighting it has proven quite insufficient to meet actual costs of delivery. (Lakehead University, 1984, pp. 37-39 and pp. 76-77) In both cases, the universities are more or less free to spend the total monies they receive as a result of these different methods of calculation as 
they see fit. It should perhaps be noted that in both cases there has been fiscal restraint applied in recent years.

The dilemma of the northern Ontario universities in terms of financing is that they are linked to a system-wide, essentially enrolment driven, formula for the vast majority of their income. This means they are placed in a directly competitive situation for students with larger more established universities that are better able to compete for those students and develop a more judicious mix of those students to maximize what are known as Basic Income Units (BIU's). This was not a specifically northern dilemma, it was a dilemma for all of the newer and especially the smaller institutions established in the 1960's.

Cameron has mistakenly asserted that the "northern dilemma" is the higher operating costs of the northern universities in Ontario. He argues that "there is compelling evidence to suggest that per student overhead costs will be higher in the north regardless of the size of the institutions involved or the particular objectives of their educational programmes". (Cameron, 1978, p. 42) The two major causes of higher costs are climate and distance from the major metropolitan and governmental centres. This means higher costs for all goods and services especially such things as fuel, travel and telephone calls. Obviously, therefore, either disproportionate resources per capita have to be allocated to northern institutions or lower quality than in the south has to be accepted. If northern universities are regarded as instruments of social development that may have an economic return their higher costs may be justified easily. If, however, they are simply regarded as access points to the general university system, as seems to be the case in Ontario, these higher costs are more difficult to justify. Difficult or not, the government of Ontario has accepted since 1975/76 that special grants should be given to Lakehead and Laurentian. These northern grants have been pegged at $11 \%$ of the operating budgets of each of the two institutions. Thus Cameron's northern dilemma is largely fictitious.

Perhaps because the Swedish educational system is fairly tightly controlled by the state and the employees are civil servants there has been a deliberate effort made to make the voice of the regions felt in relation to higher education to counteract the possibility of overcentralization. Ironically, the result has been that the northern universities in Sweden are more closely linked to all regions in which they exist than is the case in northern Ontario where the universities are autonomous.

One device for linkage in both systems is the Governing Board of the University. They are not, however, strictly comparable because a Swedish University Board is more like a mixture of a Board and a Senate in Ontario. Nevertheless, a conscious effort is made to ensure that the 1/3 Swedish governmental nonuniversity appointees are representative of the major interest groups in the region. In the case of both Lakehead and Laurentian there is relatively little representation of the wider regions of which the universities are a part and the Boards have tended to become almost self-perpetuating cliques despite some governmental appointments. 
A more important device for trying to balance regional and national interests in Sweden is that of the Regional Boards for Higher Education for which no equivalent exists in Ontario. Sweden is divided into six regional higher educational zones with one of the six full universities as its core and several other institutions. The Regional Board for northern Sweden has Umea as its core university with Lulea, Ostersund and Sundsvall/Harnosund as the peripheral institutions. The Regional Board is made up of 19 representatives of the region appointed by the government. Informally, the government appoints from nominees of the various political parties in rough accordance with their relative strength and attempts to ensure the representation of a wide selection of public interest groups. Five of the nineteen appointees come from the academic sector. One role of the Boards is to coordinate the activities of the various institutions in the region so that duplication may be avoided. Another role is to respond to regional initiatives and undertake programs or courses of particular relevance to the region. Roughly $12 \%$ of educational program monies are made available to the Regional Boards for the purpose of developing local study programming not included in the five major state controlled program areas. In general these Boards have had a rather passive role but on occasion they have mobilized regional support and pressure to be applied to either the central control bureaucracy, the UHA, or the Ministry of Education directly. Sometimes this pressure has been assisted by politicians from the region. (Lund/Malmo Regional Board of Higher Education, 1984)

Although no equivalent device exists in Ontario, it is interesting to note that Lakehead University suggested to the Bovey Commission that widely representative Regional Boards for Northwestern and Northeastern Ontario be established to advise the Ministry of Education on the special problems of the north. (Lakehead University, 1984, p. 143) This was done because it was thought the existing advisory body, the Ontario Council on University Affairs, was dominated by southern universities and interests that did not adequately take account of the special needs of the north.

Perhaps because of these structural differences the higher educational institutions in northern Sweden seem not to have been accused, as have their northern Ontario counterparts, of having poor community relations and not fully serving the interests of the region. Of course, in northern Ontario the universities are largely autonomous so if they do not serve regional interests it is seen as being their fault even if the hands of the universities are, in fact, tied by governmental funding formulae. In northern Sweden there is such tight control over core programming by the state that the state is clearly seen as the culprit not the university. In addition, non-core programming is at least influenced by Regional Boards of which the universities only comprise a part.

The relatively minimal incorporation of the northern universities into the wider northern Ontario society is not, however, only structural. They are, of course, relatively new and began with faculty who had not only little regional identification but little identification with Canada for there was a heavy reliance on 
imported American, British and other foreign academics. Because of this, and because they were originally undergraduate, non-research institutions, they produced little research of applicability to the region. Moreover, because they were basically liberal arts and science in approach they initially produced few of the types of graduates needed by the region such as doctors, dentists, nurses, social workers, engineers or foresters. Only after much struggling have Lakehead and Laurentian reoriented their programming such that it is of greater regional relevance. However, the prospect of becoming a training ground for doctors and dentists seems as remote as ever it was, despite the need and despite the failure of other measures to solve the supply problem in the north.

\section{POLICY OUTCOMES}

The relative success of the two northern university systems can really only be properly judged by comparing policy outcomes. Here they will be compared on the basis of the degree to which they have helped to increase the supply of various types of professionals in their respective regions, the degree to which access to postsecondary education has been enhanced, and the degree to which useful research has been undertaken.

Perhaps the major success for the higher education system in Norrland has been its effect on the supply of specialists in the region. As was previously indicated, the first and perhaps most important reason for the establishment of higher education in northern Sweden was to reduce the shortage of doctors. Thus medical and dental schools were the first units to be established in the region. (Lane, 1984, p. 366) The Faculty of Medicine at Umea attracts students from all over Sweden but roughly one half come from Norrland. More than half of the graduating doctors stay in Norrland and fully $83 \%$ of those coming from Norrland stay in Norrland. It has been concluded therefore that:

Firstly, the Faculty of Medicine at Umea attracts students from the south who stay for service in the north. Secondly, medical students coming from the north stay in Norrland when they have been trained at Umea. (Lane, 1984, p. 366)

While this is indeed so, there are still fewer doctors in the north than in the south where, as in Ontario, there is something of an oversupply. In the case of dentists, however, Lane states that "the findings indicate clearly that the dental training program has relieved the need for dentists in Norrland". (Lane, 1984, p. 366)

The contrast with northern Ontario in this respect is alarming. There is a serious doctor and dentist shortage in the north despite a large number of special programs intended to improve health service delivery in the region. Several of the southern medical schools operate, in effect, outreach programs in the north (primarily McMaster, The University of Western Ontario and The University of Toronto). The Ministry of Health operates a financial incentive scheme intended to attract family practitioners and dentists to remote areas and gives financial support for 
specialists visits. The Ministry of Northern Affairs offers bursaries if students promise to practice in the north for a period after graduation and operates a fairly sophisticated air ambulance system. While all these programs have had some effect the situation is still bad and is rather reminiscent of the situation in northern Sweden prior to the establishment of the Faculty of Medicine at Umea.

In terms of technical personnel, the relative situation of northern Ontario is better than it is in the medical field but still not as good as in Norrland. Lulea began as a technical university deeply imbedded in the region which attempted to meet regional needs and to obtain governmental support for this objective. In this it has been very successful. Lane indicates that "more than half of the students who have graduated from the College of Lulea have stayed to work within Norrland". (Lane, 1984, p. 367) Moreover, he says Lulea has not only served existing industries but helped the establishment of new ones with ten new firms being created on the basis of innovations stemming from research at the College. (Lane, 1984, p. 367) Moreover, large companies from elsewhere have been attracted to Lulea as a site for new business, especially the computer and electronics industries.

The same claims cannot be made for Lakehead and Laurentian where it was actually a struggle to establish fully fledged engineering programs. Even once established they had great difficulties expanding to their full potential and have not yet done so. Part of the reason was internal to their own universities. Since these began as predominantly Arts and Science institutions the faculty tended to look on them as interlopers and as a threat. Another part of the reason was external in that that there were no regional economic development plans on the part of the government of which they could become a vital part.

In other professional areas the record has been mixed. The need for social workers was realized eventually by the two universities in northern Ontario but they began their programmes very late in the day and with great difficulty and they are by no means fully established yet. Again there was both internal resistance from established programs and no real external governmental recognition of the need or a willingness to meet it. Once again in Sweden the need for social workers was seen early, resulted in schools of social work being among the first areas established, and led to the need being met far more adequately than in northern Ontario. No exact comparison can be made in the area of Forestry because this is the responsibility of the Ministry of Agriculture in Sweden and is entirely separate from the Norrland university structure. Lakehead is the only one of the two universities in northern Ontario with a School of Forestry (and one of only 5 in Canada) and it had an uphill battle, again both internal and external, to become established - though it has finally done so. In the realm of teacher training, the Faculties of Education at the two northern Ontario universities have had a comparable success with northern Sweden in meeting regional demand.

Another indication of success for the Swedish approach has been the higher capture rate of students from the region. It is likely that this has much to do with the wider range of programs offered in northern Sweden compared with northern Ontario. It also has something to do with the fact that many school counsellors in northern Ontario went to southern universities and advised their students to either 
go to their alma maters or the older, more prestigious, southern institutions with a wider range of undergraduate and especially graduate programs. Moreover, in a system where the student has to pay for the costs of living away from home, if one had to leave a smaller regional town one might as well by-pass the northern universities and go south for only a very marginally greater cost.

Another indication of the success of the Swedish approach has been in the area of research. Research was regarded as very important at Umea right from the very beginning and was given the strong emphasis it has at the other full universities in Sweden. (Ministry of Education and Cultural Affairs, 1982; National Board of Universities and Colleges, 1984) Umea as a consequence has a wide range of research staff, projects and money and has a number of publication series. Umea also has a full set of graduate programs going all the way to the doctoral level. For a relatively small and new institution it has developed a notable reputation in the area of research and graduate programs both nationally and internationally. Lakehead and Laurentian universities on the other hand began as undergraduate institutions and had difficulty establishing research activities and attracting research money. As a consequence they have developed only a limited range and depth of graduate programs and neither university has a doctoral program. The two northern Ontario institutions are trying to reorient themselves but face difficulties resulting from the period of their formation, the systems perception of their role, and competition from the larger, more established and more conveniently located institution in southern Ontario.

Both systems, however, have had difficulty establishing a wide range of depth of regionally related research. Umea has probably done somewhat better for it has some regionally related chairs, including one in the Samic language, and has a generally deeper and more extensive research base from which to undertake regionally relevant activities. In addition, a Centre for Arctic Cultural Research has been established at Umea which conducts research on the whole circumpolar zone, including the arctic and boreal or sub-arctic regions. (Umea University, 1984) The Centre is, however, relatively recent and appears to be having some start-up difficulties. The northern Ontario universities were disadvantaged from the outset in terms of regionally relevant research because they were, as noted, created as undergraduate access points not graduate and research institutions and originally hired faculty accordingly. In addition, many of the faculty in the regionally sensitive subjects were often foreign and even if not were frequently concerned not to seem parochial by conducting regionally related research projects. However, attitudes are gradually changing and regionally related research has increased in volume. Laurentian has created the Centre of Mining and Mineral Exploration Research and Lakehead is considering a proposal for the establishment of a Centre for Northern Studies. (Lakehead University, 1985)

\section{THE FUTURE}

Over the years in Norrland there has been a shift in emphasis from meeting just the need for specific types of manpower, such as doctors and dentists, to that of 
enhancing general access to the system. In addition, there has been an increasing desire for greater "autonomy" from state control and influence in its many forms. Yet at the same time there is still a desire to be of great use to the region of which the universities and colleges are a part as witnessed, for example, by the space related work at Kiruna, the Centek Foundation at Lulea and Uminova at Umea. It is also reflected in developments such as the founding of the Centre for Arctic Cultural Research at Umea.

Over the years in northern Ontario there has been a shift in emphasis from just providing northern access points to the general university system to trying to meet regional needs for specific types of manpower as well. Although large strides have been made, largely on the initiative of the regional institutions themselves, there are a few major steps to be taken, especially in the medical manpower field. While the two northern universities wish to maintain their autonomy, they are not at all unhappy with the Bovey Commission's suggestions that there be advisory University Committees for Northwestern and Northeastern Ontario and some form of direct funding from the Ontario Ministry of Northern Affairs which, in combination, might have much the same effect as the Regional Board in northern Sweden. Both Lakehead and Laurentian universities are also keen to become more useful to their region. This is indicated by their joint Innovation North initiative which is intended to foster the commercialization of research and instructional innovations developed at the two institutions. It is also indicated by their increasing emphasis on northern related research and programming and their desire to expand this further, as with the proposal for a Centre for Northern Studies currently being discussed at Lakehead.

It would appear, therefore, that convergence has been taking place between the two systems and that this is what is likely to continue to occur. In the not-toodistant future the two systems, though originally based upon completely different rationales, may come to quite closely resemble each other in many ways.

\section{NOTES}

1. The authors would like to thank the Senate Research Committee of Lakehead University whose support for another project indirectly aided the preparation of this paper.

2. The authors would like to thank many members of the Swedish higher education system for their assistance but especially Dr. Carl-Gustav Andren, Anders Skoglund, Leif Lindfors, Dr. A. Wessman, Dr. Ringborg, Dr. Par-Erik Back, Dr. Jan-Erik Lane, Svante Ersson, Dr. Gunnel Gustafsson, Kjell Lundmark and Ulf Wiberg. Dr. George Harrower, former President of Lakehead University and Dr. Douglas C. Nord of the University of Minnesota also provided much valuable information.

\section{REFERENCES}

Axelrod, P. Scholars and Dollars: Politics, Economics and the Universities of Ontario, 1945-80. Toronto: University of Toronto Press, 1982.

Cameron, D.M. The Northern Dilemma: Public Policy and Postsecondary Education in Northern Ontario. Toronto: Ontario Economic Council, 1978.

Commission on the Future Development of the Universities of Ontario. Ontario Universities: Options 
and Futures. (Edmund C. Bovey, Chairman). Toronto: The Commission on the Future Development of the Universities of Ontario, December 1984.

Committee on University Education in Northeastern Ontario. Report. (Harry C. Parrot, Chairman). Toronto: Ministry of Colleges and University, June 1983.

Department of Treasury and Economics. Design for Development: Northwestern Ontario Region. Toronto: Queen's Printer, 1970.

Department of Treasury, Economic and Intergovernmental Affairs. Design for Development: Northeastern Ontario. Toronto: Department of Treasury, Economics and Intergovernmental Affairs, 1976.

Drouin, Paquin and Associates Ltd. Assessment of the Long Term Viability of the College Universitaire de Hearst. Toronto: Ministry of Colleges and Universities, September 1982.

Lakehead University. Press release on the Effect of Lakehead University on the Local Economy. Thunder Bay: Lakehead University, December 1983.

Lakehead University. Lakehead: The University of Northwestern Ontario. (Submission to the Commission on the Future Development of the Universities of Ontario). Thunder Bay: Lakehead University, 1984.

Lakehead University, Report of the Presidential Advisory Committee on Northern Studies. Thunder Bay: Lakehead University, 1985.

Lane, J.E. Creating the University of Norrland: Goals, Structures and Outcomes. Umea: CWK Gleerup, 1983.

Lane, J.E. Higher Education Regionalization. Higher Education, 1984, 13, 347-368.

LeDuc, L. \& White, W.L. The Role of Opposition in a One Party Dominant System: The Case of Ontario, paper read at Canadian Political Science Association annual meeting. Montreal, June 1972.

Lund/Malmo Regional Board of Higher Education. Higher Education in Sweden: The Regional Boards. Lund: Lund/Malmo Regional Board of Higher Education, 1984.

McLarty, J.K. Organization of Higher Education for Improved Access, Equity and Spatial Justice in Primary Resource Regions: The Case of Northern Ontario, Canada, Ph.D. dissertation, Michigan State University, 1979.

Miller, T. Cabin Fever: The Province of Ontario and Its Norths, in D. MacDonald (ed.) Government and Politics of Ontario (2nd ed.). Toronto: Van Nostrand Reinhold, 1980, 227-244.

Ministry of Education and Cultural Affairs. The Reform of Higher Education. Stockholm: Ministry of Education and Cultural Affairs, 1978.

Ministry of Education and Cultural Affairs. Research in Sweden. Stockholm: Ministry of Education and Cultural Affairs, 1982.

National Board of Universities and Colleges. Looking at Learning: Higher Education and Research in Swedish Society. Stockholm: National Board of Universities and Colleges, 1984.

National Board of Universities and Colleges. The National Swedish Board of Universities and Colleges. Stockholm: National Board of Universities and Colleges, 1984.

National Board of Universities and Colleges. Higher Education and Research in Sweden 1984/1985. Stockholm: National Board of Universities and Colleges, 1984.

Ontario Council on University Affairs. The Ontario University System: A Statement of Issues. (Fifth Annual Report). Toronto: Ontario Council on University Affairs, 1979.

Ontario Council on University Affairs. A Proposal for Structural Change in the University System of Northeastern Ontario. Toronto: Ontario Council on University Affairs, 1981.

Ontario Council on University Affairs. Ninth Annual Report (1982-1983). Toronto: Ontario Council on University Affairs, 1983.

Ontario Economic Council. Northern Ontario Development. Toronto: Ontario Economic Council, 1976. 
Organization for Economic Cooperation and Development. Educational Reforms in Sweden. Paris: O.E.C.D. 1981 .

Premfors, R. Analysis in Politics: The Regionalization of Swedish Higher Education. Comparative Education Review, 1984, pp. 85-104.

Premfors, R. \& Ostergren, B. Systems of Higher Education: Sweden. New York: International Council for Educational Development, 1978.

Royal Commission of Inquiry Into Algoma University College. Final Report. (Commissioner John H. Whiteside Q.C.) Toronto: Ministry of Colleges and Universities, 1977.

Scott, D. Northern Alienation, in D. MacDonald (ed.). Government and Politics of Ontario. Toronto: MacMillan, 1975, 235-248.

Silcox, P. Some Problems of Opposition Leadership in Ontario Provincial Politics, paper read at Fortieth annual meeting of the Canadian Political Science Association. Calgary, June 1968.

Stephenson, B. Statement by the Minister of Colleges and Universities on the Restructuring of the University System in Northeastern Ontario to the Legislature. Toronto, October 1982.

Umea University. Center for Arctic Cultural Research, Umea University. Umea: Umea University, 1984.

Weller, G.R. Hinterland Politics: The Case of Northwestern Ontario. Canadian Journal of Political Science, 1977, 10(4), 727-754.

Weller, G.R. Resource Development in Northern Ontario: A Case Study in Hinterland Politics, in O.P. Dwivedi (ed.). Resources and the Environment: Policy Perspectives for Canada. Toronto: McClelland and Stewart, 1980, 243-269.

Weller, G.R. Universities, Politics and Development: The Case of Northern Ontario, paper read at the International Symposium on the Role of Universities in Developing Areas, Beer Sheva, Israel, December 1983.

Wilson, J.S. \& Hoffman, D. Ontario: A Three Party System in Transition, in M. Robin (ed.). Canadian Provincial Politics: The Party Systems of the Ten Provinces. Scarborough: Prentice Hall, 1972. 